\title{
Resource competition between macrobenthic epifauna and infauna in a Kenyan Avicennia marina mangrove forest
}

\author{
J. Schrijvers*, H. Fermon, M. Vincx \\ University of Gent, Department of Morphology, Systematics and Ecology, Marine Biology Section, K.L. Ledeganckstraat 35 , \\ B-9000 Gent, Belgium
}

\begin{abstract}
A cage exclusion experiment was used to examine the interaction between the epibenthos (permanent and visiting) and the macroinfauna of a high intertidal Kenyan Avicennia marina mangrove sediment. Densities of Oligochaeta (families Tubificidae and Enchytraeidae), Amphipoda, Insecta larvae, Polychaeta and macro-Nematoda, and a broad range of environmental factors were followed over 5 mo of caging. A significant increase of amphipod and insect larvae densities in the cages indicated a positive exclusion effect, while no such effect was observed for oligochaetes (Tubificidae in particular), polychaetes or macronematodes. Resource competitive interactions were a plausible explanation for the status of the amphipod community. This was supported by the parallel positive exclusion effect detected for microalgal densities. It is theretore hypothesized that competition for microalgae and deposited food sources is the determining structuring force exerted by the epibenthos on the macrobenthic infauna. However, the presence of epibenthic predation cannot be excluded.
\end{abstract}

KEY WORDS: Macrobenthos - Infauna - Epibenthos - Exclusion experiment - Mangroves - Kenya

\section{INTRODUCTION}

Exclusion experiments are a valuable tool for detecting the influence of epibenthic animals on endobenthic communities. Most studies have been conducted in temperate intertidal, soft and unvegetated areas (Reise 1977, Virnstein 1977, 1979, Hulberg \& Oliver 1980, Federle et al. 1983, Gee et al. 1985, Marinelli \& Coull 1987. Hall et al. 1990a), soft seagrass-covered coastal zones (Young et al. 1976, Orth 1977, Reise 1977, 1978. Young \& Young 1977, Virnstein 1978) or salt marshes (Bell 1980, Hoffman et al. 1984). In general, predation was accepted as the obvious epibenthic influence on the macro- and meiofauna. About half of the studies which excluded large epibenthic predators mentioned an at least 2-fold increase in total endobenthic prey abundance (Reise 1985)

Mangrove areas are soft vegetation-covered zones characteristic of tropical coasts. It is frequently men-

\footnotetext{
-E-mail: jan.schrijvers.rug.ac be
}

tioned that these areas are intensively used by epibenthic animals as feeding grounds, nursery areas and shelters (Hutchings \& Saenger 1987). In order to assess the importance of the endobenthic community under the mangrove trees as a food source, exclusion experiments were conducted in a Kenyan Avicennia marina stand. Detection of epibenthic predation in such a high intertidal zone would indicate that the mangrove forest floor, and not only the creeks and flats surrounding it, are of importance as a feeding ground for the epibenthos.

The few exclusion studies that have been conducted in mangroves focused mainly on the meiobenthos (Dye \& Lasiak 1986, Alongi 1989, Dittman 1993, Schrijvers et al. 1995), leaving the macrobenthos ( $>0.5 \mathrm{~mm}$ ) as an interesting endobenthic category yet to be studied. When dealing with high intertidal Avicennia marina sediments, it is expected that the impact of the permanent epihenthos is more important than that of visiting fauna. These resident organisms are mainly leaf shredders and selective or nonselective deposit feeders (crabs and gastropods). It is hypothesized that ex- 

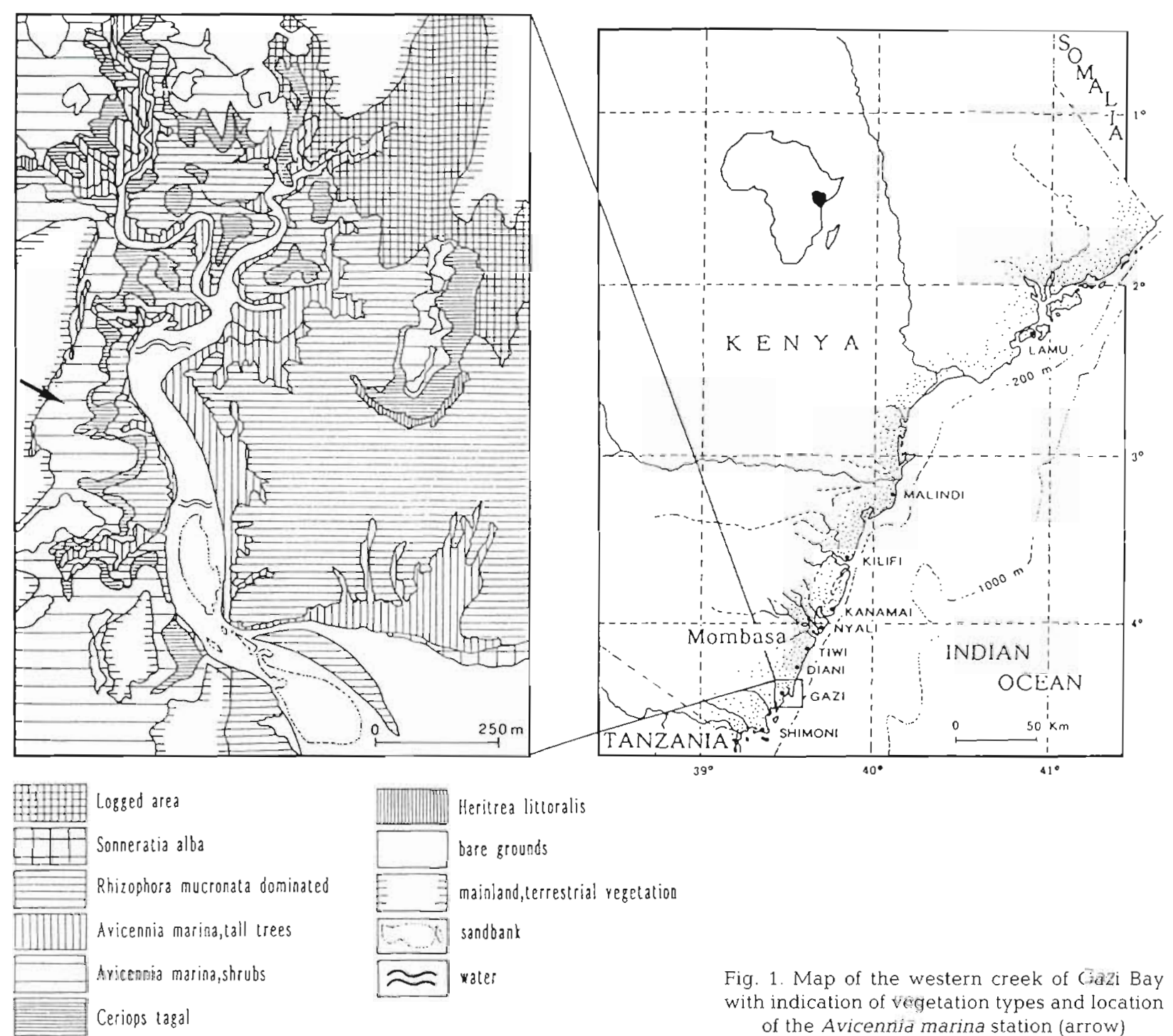

Fig. 1. Map of the western creek of Gazi Bay with indication of vegetation types and location of the Avicennia marina station (arrow)

clusion of the epibenthos would therefore result in: (1) leaf accumulation, favouring infaunal leaf shredders; (2) accumulation of detritus, bacteria, protozoans and microalgae, favouring infaunal deposit feeders.

\section{MATERIAL AND METHODS}

Study area. The study site was a non-exploited Avicennia marina mangrove vegetation zone bordering the westbank of the western creek of Gazi Bay, about $50 \mathrm{~km}$ south of Mombasa, Kenya (Fig. 1). This zone was situated $>3 \mathrm{~m}$ above mean low water spring level and was thus only inundated during the high water of a spring tide. It represented a typical high intertidal mangrove forest habitat, covering a total area of $>0.5 \mathrm{~km}^{2}$ The zone was visited by several epibenthic animals (authors' pers. obs.), e.g. gobiid fish which sometimes remained in puddles during low tide. The permanent epibenthic community mainly consisted of gastropods (Terebralia palustris and Cerithidea decollata) and crabs (Sesarma meinerti and Metopograpsus thukuhar).

Experimental design. All epibenthic and hyperbenthic animals (hereafter called 'epibenthos') (>2 mm) were excluded from cages and the influence on the macrobenthic infaunal structure was followed through time. Experimental design sensu Hurlbert (1984), cage construction and execution procedures were identical to those used by Schrijvers et al. (1995). Besides the full cages (C) (an enclosed $1 \times 1 \mathrm{~m}$ sediment surface), 2 control treatments were chosen: true blanks $(B)$ and partial cages ( $\mathrm{P}$ ) (an enclosed $1 \times 1 \mathrm{~m}$ sediment surface with 1 open side). B controlled natural temporal variation, while $\mathrm{P}$ corrected for possible procedural impacts Each treatment was employed in 3 units. 
Six series of samples were taken over time:

- Period 1 before caging (6 August 1992);

- Period 2: after 22 d of caging (28 August 1992);

- Period 3: after 50 d of caging (25 September 1992);

- Period 4: after 85 d of caging (30 October 1992);

- Period 5: after 112 d of caging (26 November 1992);

- Period 6: after 139 d of caging (23 December 1992).

Core holes were immediately filled with silicon plugs or sediment bags to avoid effects on the surrounding sediment that was to be sampled later in the experiment (Marinelli \& Coull 1987).

Environmental factors. One $6 \mathrm{~cm}$ diameter core sample was taken in each unit per period to a depth of $>10 \mathrm{~cm}$. The bottom water in the sample holes was analyzed for bulk values of $\mathrm{pH}$, salinity and dissolved oxygen $\left(\mathrm{DO}_{2}\right)$ with a combined $\mathrm{pH}$ bottom electrode, a refractometer, and a Clark type 737 electrode respectively. Other measurements were performed on the upper slice and the rest fraction of the core $(0$ to $2 \mathrm{~cm}$ and $2 \mathrm{~cm}$ to rest). Temperature and redox potential were measured using a bar thermometer sensitive to $0.01{ }^{\circ} \mathrm{C}$ and a combined redox electrode respectively. The percentage of particulate organic matter (POM) and some granulometric variables were determined. After drying at $100^{\circ} \mathrm{C}$, the POM was quantified via the loss in weight following combustion at $600^{\circ} \mathrm{C}$ for $4 \mathrm{~h}$. A Coulter ${ }^{R}$ LS Particle Size Analyser was used to charac- terize the granulometry of the sediment. This analysis was done both before and after combustion at $600^{\circ} \mathrm{C}$. Before analysis, the $>1 \mathrm{~mm}$ fraction was mechanically separated by sieves. It consisted mainly of root material. An important granulometric characteristic was the median of the sediment. This is a measure for the general grain-size tendency of the sediment and corresponds to the $50 \%$ line of the cumulative distribution curve (Holme \& McIntyre 1984). The lower this median, the siltier the sediment (negatively correlated with the \% of mud).

The upper layers of a $1 \mathrm{~cm}$ diameter core 10 to $2 \mathrm{~cm}$ and 2 to $4 \mathrm{~cm}$ ) were used to estimate the percentage of organic carbon with a Carlo Erba NA 1500 series 2 C. analyser These layers were also analyzed for chlorophyll $a$ and fucoxanthin pigment concentrations (using a Gilson HPLC-chain according to a slightly modified method of Mantoura \& Llewellyn 1983). Chlorophyll a could be correlated with the general concentration of microalgae in the sediment (Gerold \& Hughes 1994a). Fucoxanthin pigments pointed to diatoms in particular (D. Van Gansbeke pers. comm.).

Biotic factors. Endobenthic samples were obtained by taking 1 handcore $(12.5 \mathrm{~cm}$ diameter) (Fig. 2) per unit (with 3 replicate units per treatment). The long handle permitted sampling of the cage and partial cage treatments without disturbing the surrounding
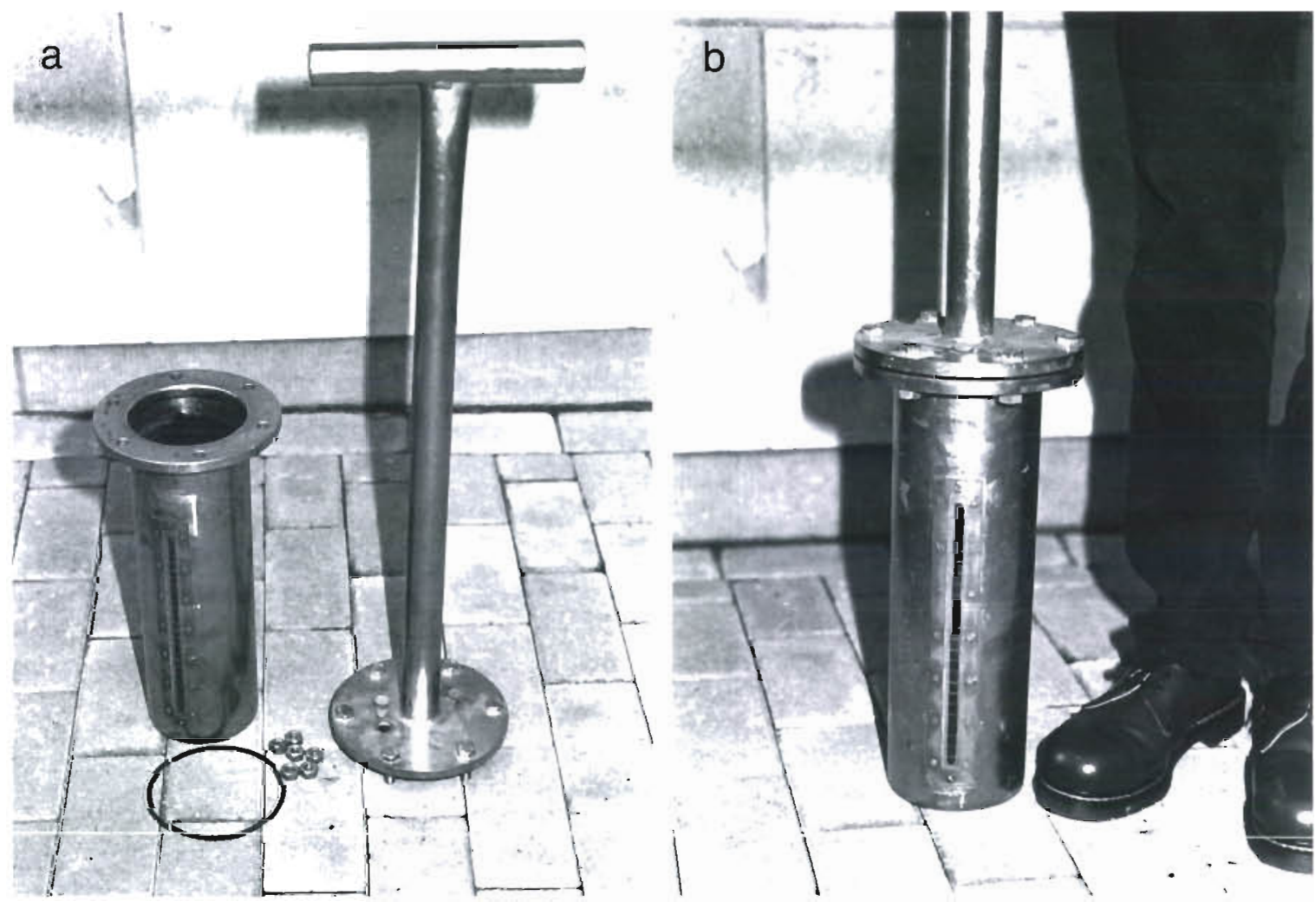

Fig. 2. Corer for macrofauna samples. Components (a) separated and (b) attached 
sediment. The core was taken to a depth of $20 \mathrm{~cm}$ and divided into 2 parts consisting of the top $2 \mathrm{~cm}$ and the rest. Before sieving, both parts were preserved in a cold $8 \%$ neutralized formalin solution. Extraction of macrofauna from the sediment was achieved by sieving with mesh sizes of $0.5,1$ and $2 \mathrm{~mm}$. All the taxa (Oligochaeta, Amphipoda, Polychaeta, Insecta larvae, Nematoda, Gastropoda and Cnidaria) were counted. Several trials revealed that less than $10 \%$ of the macrofauna occurred deeper than $2 \mathrm{~cm}$. This led us to concentrate only on the upper layer. Densities are expressed as numbers of individuals per $1 \mathrm{~m}^{2}$.

The oligochaetes of 2 replicates of Periods 1,2 and 5 and all the insect larvae were identified to family and the amphipods, polychaetes and nematodes to genus level.

Amphipod length (from peduncle to telson) was measured with a drawing mirror under a stereoscopic microscope. The average individual amphipod length per sample was calculated in order to test for adult invasion or reproduction in the cages.

Statistical analysis. An analysis of variance (ANOVA) was used to test for significant differences of macrofauna densities in different treatments ( $B, P$ and C) and periods ( 1 to 6 ) for the top $2 \mathrm{~cm}$ of the sediment. A $3 \times 6$ between-groups factorial design (f) was used, considering treatments and periods as independent groups. The total variance of all groups was used as error variance in the analysis. Moreover, a 3 (between groups) $\times 6$ (within subjects) mixed design (m) was constructed, with treatments as groups and periods as subjects repeated over time. In this case, error variance was limited to the within-period variances. Detailed comparison between groups was made by contrast analysis. Exclusion effects $(E)$ were defined as significant differences $(p<0.05)$ between cage and blankpartial cage, while procedural effects ( $\mathrm{Pr}$ ) yielded significant differences $(p<0.05$ ) between cage-partial cage and blank. The density data were root-root transformed, and the \% values of environmental factors were transformed angularly to meet the ANOVA assumptions (normality, homogeneity of variances, and non-correlation between means and variances).

In those cases where these assumptions were not met, the non-parametric Kruskal-Wallis and Median tests were applied (e.g. for oligochaete family densities using only 2 replicates).

\section{RESULTS}

\section{Endobenthic composition}

The endobenthos was composed of the following taxa - Oligochaeta: families Tubificidae (mainly Ainu- drilus sp.) and Enchytraeidae (mainly Marionina sp.) (C. Erseus pers comm.);

- Insect larvae: families Dolichopodidae and Limoniidae (B. Goddeeris pers. comm.);

- Amphipoda: family Grandidierellidae (Grandidierella sp.) (S. De Grave pers. comm.);

- Polychaeta: families Nereidae (Namalycastis sp.) and Opheliidae (Armandia sp.) (Day 1967);

- Nematoda: family Oncholaimidae (mainly Oncholaimus sp.) (Platt \& Warwick 1988);

- Gastropoda: not identified;

- Cnidaria not identified.

While comparisons between temperate and tropical regions usually reveal a higher benthic diversity in the latter, the number of taxa in this mangrove study was low. This probably reflects the high intertidal position of the sampling site, which resulted in extreme anaerobic conditions with abrupt changes in salinity, temperature, redox and $\mathrm{DO}_{2}$ (Tietjen \& Alongi 1990).

Fig. 3 shows the relative abundance (average of all blank units over all periods) of the macrobenthic taxa. It is clear that the oligochaetes $(78 \%$ tubificids and $22 \%$ enchytraeids) made up the largest part of the

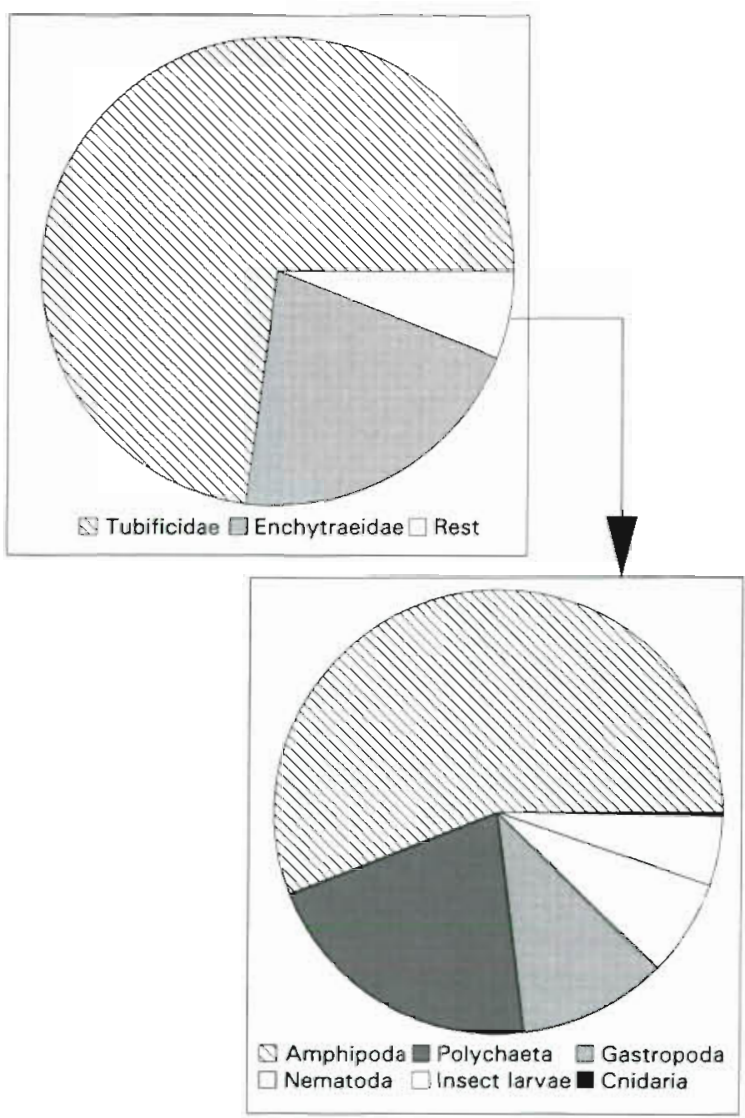

Fig. 3. Relative abundance (\%) of the major macrobenthic infaunal taxa and oligochaete families (average of blank sites over all periods) 
macrobenthic infauna (94\%). Within the remaining $6 \%$, the amphipod genus Grandidierella (56\%) dominated. It was followed by the polychaete genus Namalycastis (21\%), gastropods $(10.7 \%)$, macrobenthic nematodes $(7 \%)$, insect larvae $(5 \%)$ and cnidarians $(0.3 \%)$. The polychaete genus Armandia was found only in the sediment of one single cage unit in Period 5.

\section{Experimental results}

Environmental factors

Exclusion effect. A highly significant exclusion effect after 50 and $85 \mathrm{~d}$ of caging was demonstrated for the concentration of chlorophyll a. Chlorophyll $a$ increased about $5 \times$ in the cage as compared to the other treatments (Fig. 4a).

Also, the median grain size before combustion (negatively correlated with the \% of mud before combustion) underwent a significant exclusion effect after $112 \mathrm{~d}$ of caging, showing a $1.5 \times$ decrease in the cages compared to the partial cage and blank treatments (Fig. 4b). This effect was not found for median grain size after combustion and was therefore related to the muddy detritus fraction.

Procedural effect. As a result of the cage and partial cage construction, the sediment underwent a salinity decrease between 0 and 22 d of caging (Fig. 5a).

Both statistical designs (factorial and mixed) indicated a procedural treatment effect for $\mathrm{pH}$, with a more acidic sediment in the blank units throughout the experiment (Fig. 5b).

The median grain size after combustion (which is in general negatively correlated with the inorganic muddy fraction) showed a decrease in the cages and partial cages as compared to the blanks. This led to a procedural effect after 112 experimental days (Fig. 6).

A possible procedural impact on redox potential could not be detected since practical problems made it inipossible to measure this variable during the first 2 periods.

No effect. No clear effect was detected for all other variables (including the \% of POM). a. Chlorophyll a concentration (ng/g DWT)

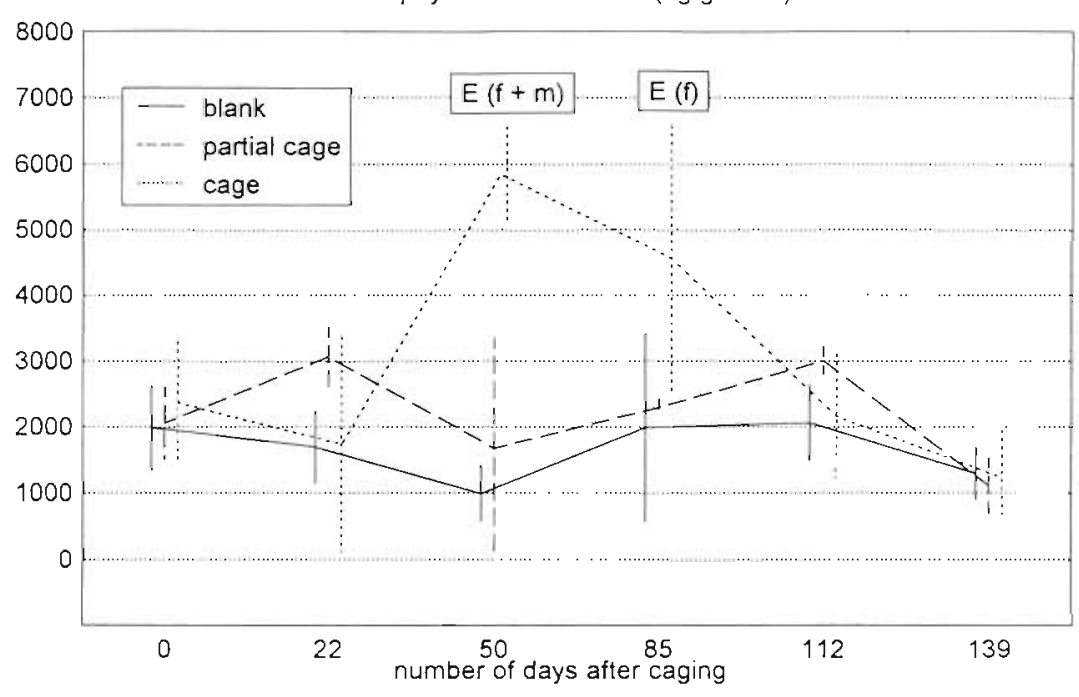

b. Median before combustion $(\mu \mathrm{m})$

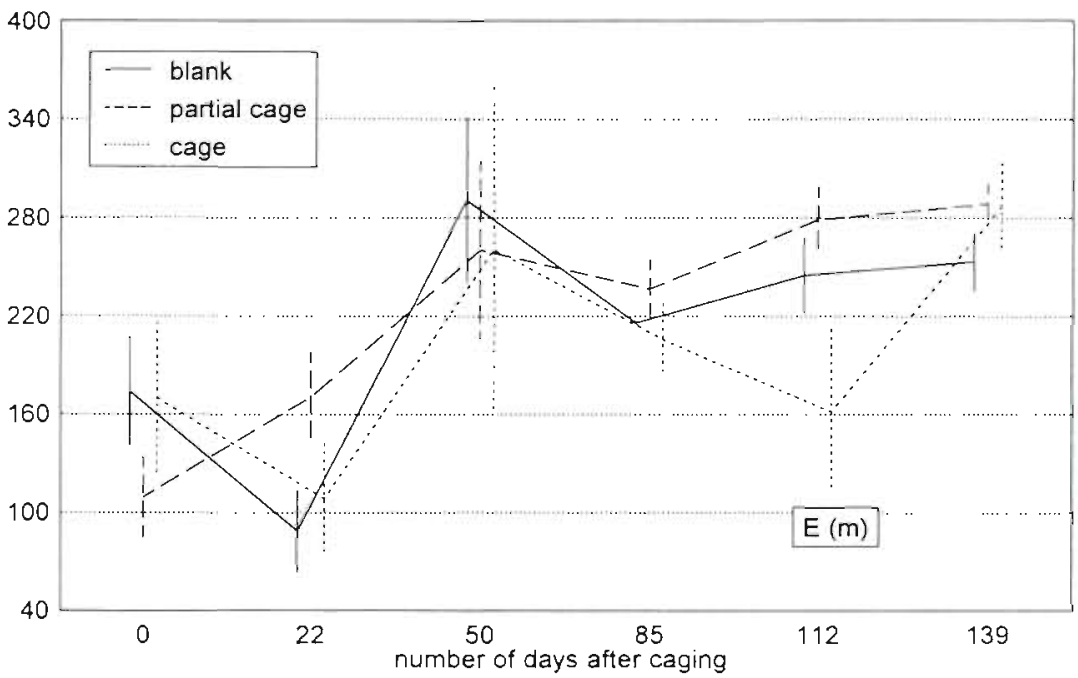

Fig. 4. Exclusion effect ( $E$ : significant effect with $p<0.05$; f: factorial design, $m$ : mixed design) on (a) chlorophyll a concentration and (b) median grain size before combustion. Mean values and standard deviations of the upper slice 10 to $2 \mathrm{~cm}$ j over time for the cage, partial cage, and blank treatment

\section{Biotic factors}

Exclusion effect. Cage amphipod densities exceeded those of partial cage and blank sediment from Day 85 of the experiment onwards with a factor of 4 to 5 . This increase was confirmed by an overall significant exclusion effect (Fig. 7a).

The average individual amphipod length did not differ significantly among treatments (Fig 7h)

The density of insect larvae increased significantly after $85 \mathrm{~d}$. A significant exclusion effect was detected after 85 and 139 d, cage densities reaching 5 
a. Salinity (psu)

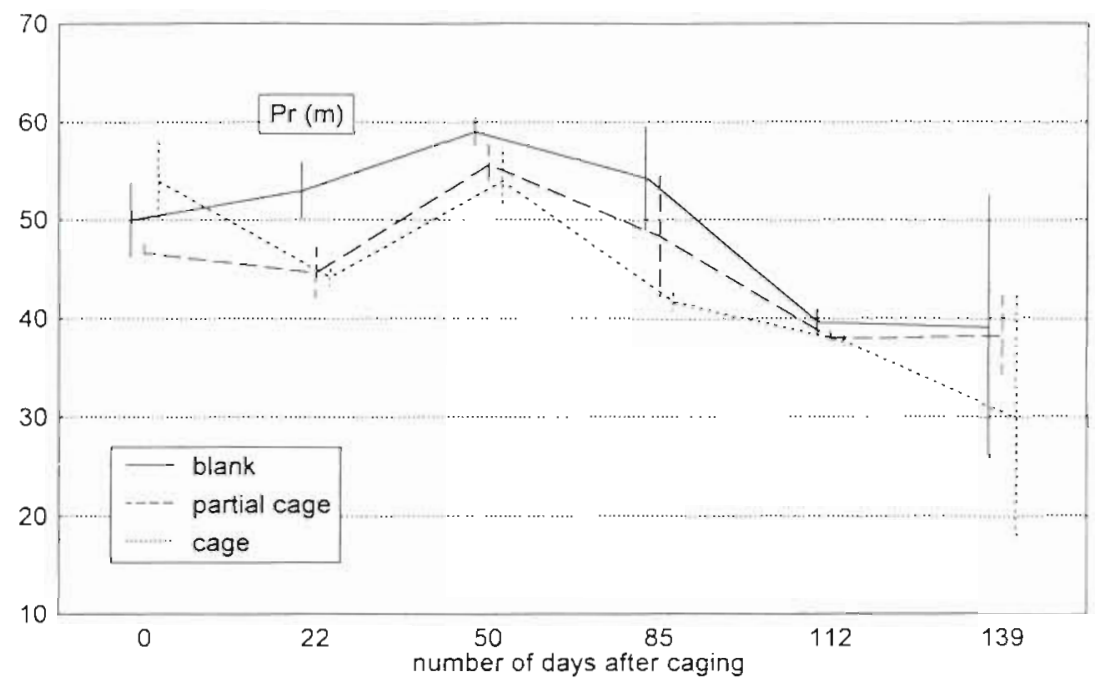

๖. $\mathrm{pH}$

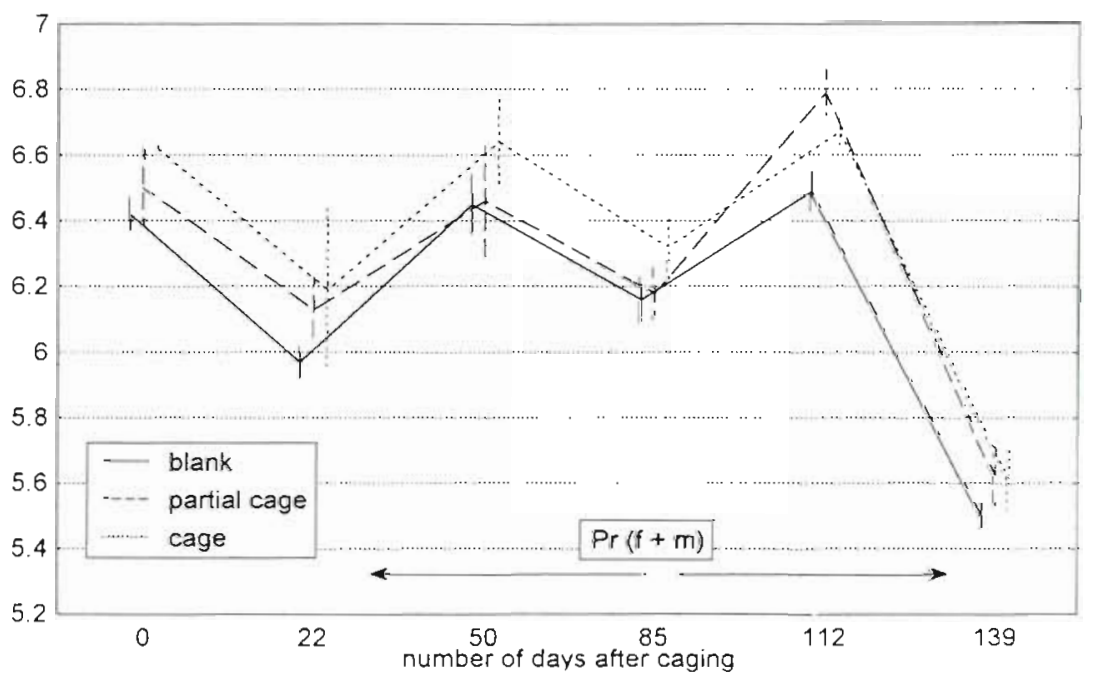

Fig. 5. Procedural effect. (Pr: significant effect with $p<0.05$, f: factorial design, m: mixed design) on (a) salinity and (b) pH. Mean values and standard deviations of the upper slice $(0$ to $2 \mathrm{~cm}$ ) over time for the cage, partial cage, and blank treatment

to $6 \times$ higher levels than in the other treatments (Fig. 8).

Procedural effect. Already after $22 \mathrm{~d}$, a significant procedural effect was detected for oligochaete densities. This effect was repeated after 2 mo. The cage and partial cage densities slightly surpassed the blank density (Fig. 9a).

Table 1 shows the results of the Kruskal-Wallis and Median tests on the Tubificidae and Enchytraeidae densities for Periods 1, 2 and 5. Neither test detected any effect. Nevertheless, the Median test suggested a procedural effect for the Tubificidae after 112 caging days: a significant difference $(p<0.05)$ was observed between the blank and partial cage treatment which was not detected before this period.

As the oligochaetes made up $94 \%$ of the total macro-infaunal density, trends in the total community were inextricably linked with oligochaete trends (Fig 9b).

No effect. Neither procedural nor exclusion effects were detected for polychaetes (Fig. 10a), macronematodes (Fig 10b), gastropods and cnidarians.

\section{DISCUSSION}

\section{Experimental design}

The characteristics of the applied experimental design have been discussed by Schrijvers et al. (1995).

All epibenthic fauna ( $>2 \mathrm{~mm}$ ) was non-selectively excluded in this study and the most conspicuous observed effects are believed to result from the removal of the dominant epibenthos Larger mesh sizes (above $2 \mathrm{~mm}$ ) have been shown to reduce the exclusion effect (Reise 1977, 1978, Kneib \& Stiven 1982) while a smaller mesh ( $<2 \mathrm{~mm})$ was expected to enhance fouling.

In analogous studies conducted in temperate regions, where predation is believed to be the driving force structuring endobenthic communities, significantly increasing macrobenthic densities near the sediment surface were the dominant exclusion effect (Virnstein 1977, 1979, Holland et al. 1980). We therefore only analyzed the upper sediment layer. Moreover, several trials revealed that less than $10 \%$ of the macrofauna occurred deeper than $2 \mathrm{~cm}$.

With respect to the available literature, the following should be taken into account:

(1) Most of the unsuccessful experiments (no effects or only procedural effects) have not been published. This leads to wrong conclusions concerning experimental efficiency and benthic interaction levels (Hulberg \& Oliver 1980, Connell 1983).

(2) The influence of epibenthic predators or competitors on infaunal density and diversity is bound to vary with habitat, season, and succession phase. These factors are usually not mentioned (Holland et al. 1980). 
Fig. 6. Procedural effect (Pr: significant effect with $p<0.05$, f: factorial design) on median grain size after combustion. Mean values and standard deviations of the upper slice $(0$ to $2 \mathrm{~cm})$ over time for the cage, partial cage, and blank treatment

\section{Experimental results}

Environmental factors

Microalgae. The clear exclusion effect on the chlorophyll a concentration is correlated with the density of microalgae in the sediment (Admiraal 1977. Gerdol \& Hughes 1994a). The

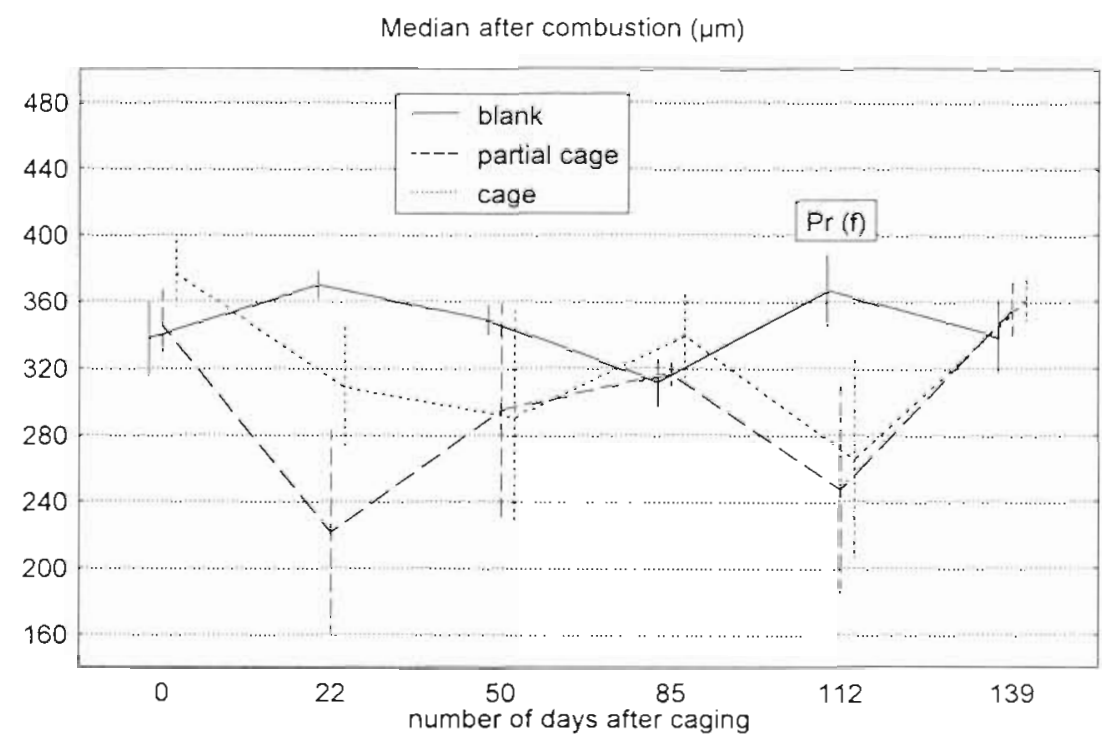

a. Amphipod density (Grandidierella) (ind $/ \mathrm{m}^{2}$ )

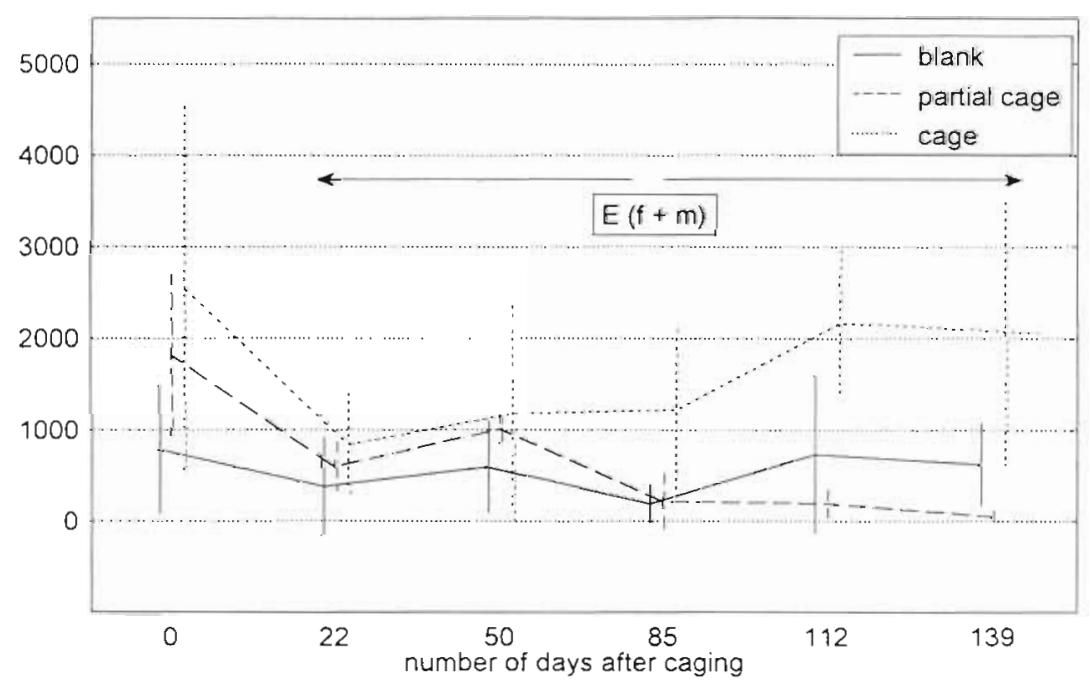

b. Average individual amphipod length ( $\mathrm{mm}$ )

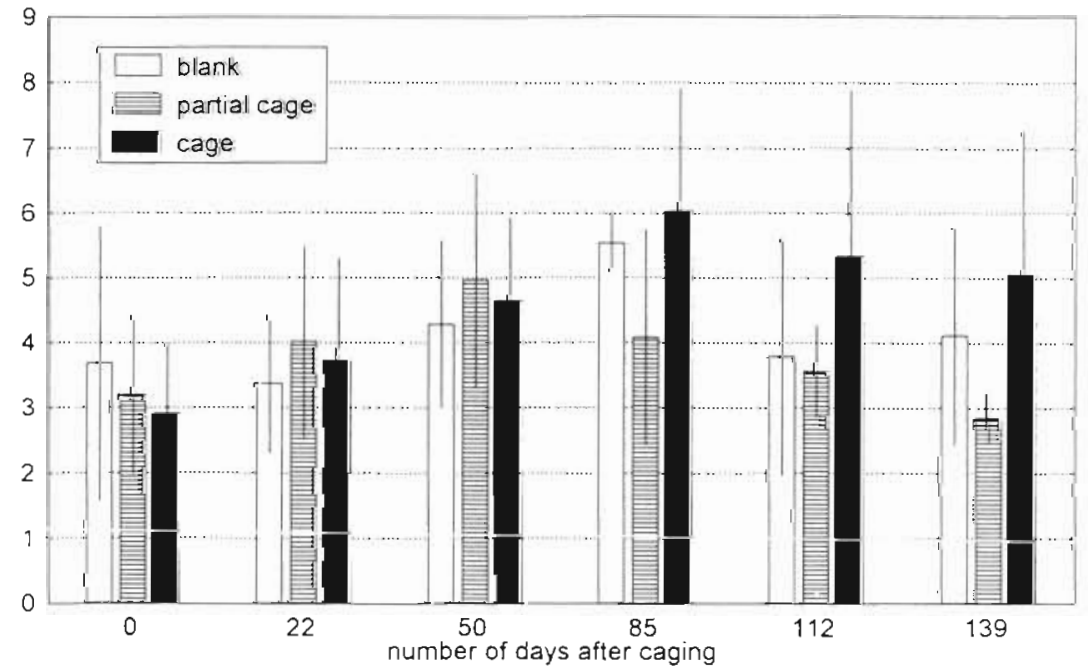

increase possibly results from the exclusion of the microalgae feeding epibenthos (Table 2). Microalgal growth can also be a response to a release of nutrients from previously deposited mud. However, this was not evident from our study.

Sediment texture and detritus. Several studies showed that mud and detritus deposition can be due to procedural effects in exclusion cages Virnstein 1977, Hulberg \& Oliver 1980, Woodin 1981, Menge et al. 1986, Schrijvers et al. 1995), probably as a result of increased water stagnation. This effect can possibly attract or repel certain infaunal species (Hulberg \& Oliver 1980, Heip et al. 1985). In this study, a decrease of the median grain size of the inorganic sediment fraction indicated a shift to a slightly siltier condition due to the cage construction (after $112 \mathrm{~d}$ ).

However, the exclusion effect on the median grain size before combustion (which is negatively correlated with the percentage of mud before combus-

Fig. 7 (a) Amphipod density and (b) average individual amphipod length in the cage, partial cage and blank treatment. Mean values and standarad devldiions of ìite upper slice $(0$ to $2 \mathrm{~cm}$ ) over time. E: significant exclusion effect with $p<0.05$, f: factorial design, m: mixed design 
Fig. 8. Insect larvae density in the cage, partial cage and blank treatment. Mean values and standard deviations of the upper slice $(0$ to $2 \mathrm{~cm}$ ) over time. E: significant exclusion effect with $p<0.05$, f: factorial design, m: mixed design

tion) suggests the muddy detritus to be marginally influenced by the exclusion.

Physicochemical factors. It is obvious that the sediment of treatments $P$ and $C$ became more humid through time than that of treatment $B$ as a result of cage construction (PVC plates and cover) (Table 3). This resulted in lower salinities.

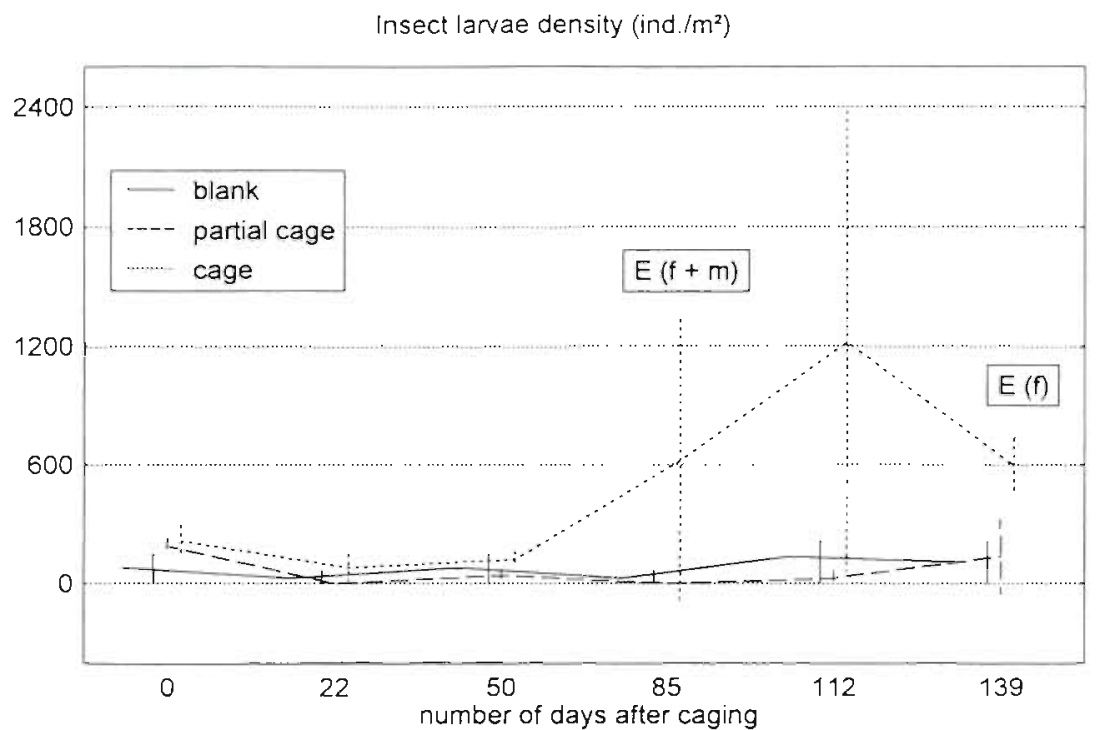

a. Oligochaete density $\left(\right.$ ind $\left./ \mathrm{m}^{2}\right)$

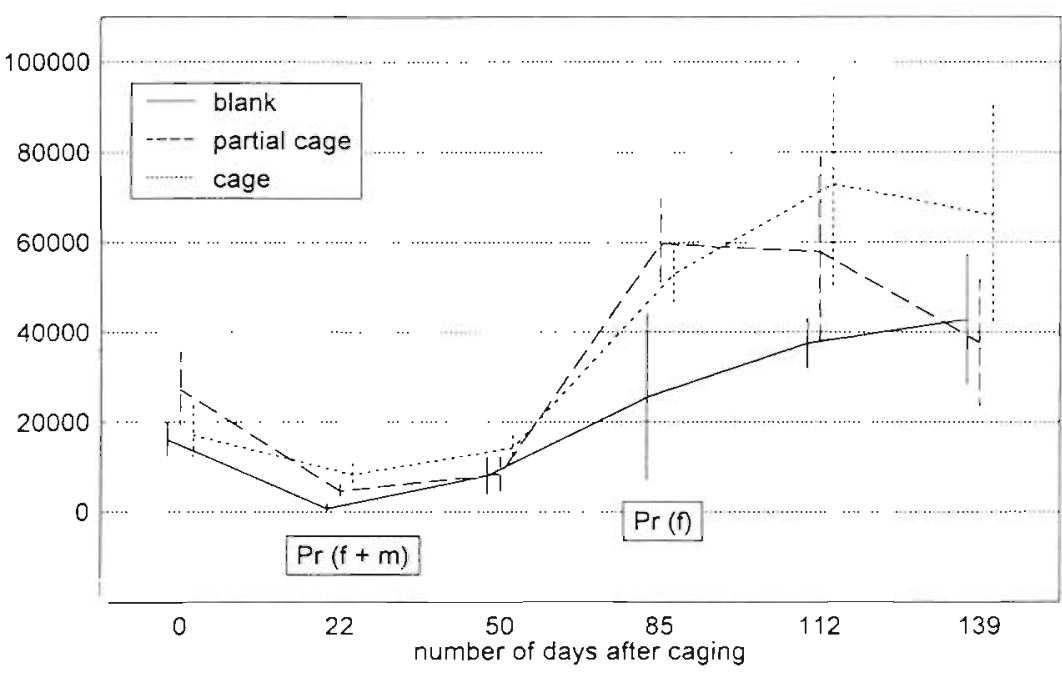

b. Total macrobenthic density (ind. $/ \mathrm{m}^{2}$ )

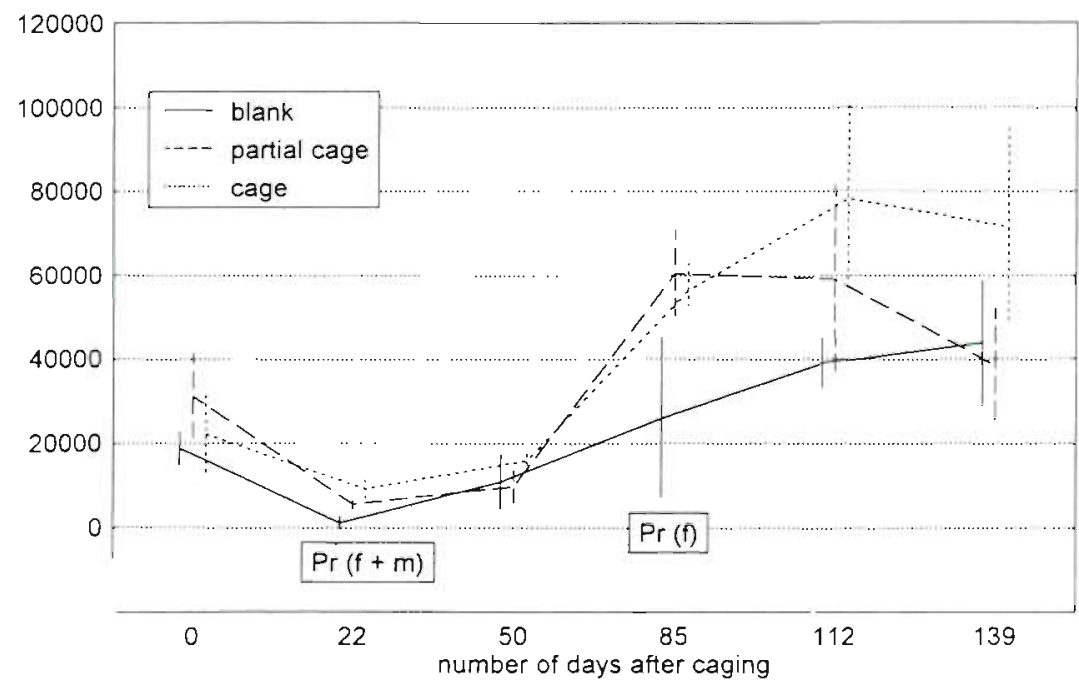

Biotic factors

Amphipod density. Gut content analysis of several individuals $(N=10)$ of the genus Grandidierella (Schrijvers unpubl.) revealed that detritus and small leaf particles, originating from the mangrove sediment, were dominant in the diet. The mangrove amphipod Parhyale hawaiensis was shown to consume large quantities of decomposing mangrove leaves (Poovachiranon et al. 1986). In general, crabs, amphipods, capitellid polychaetes and isopods seem to be breaking down mangrove leaves in small particles, egesting it as plant detritus which thus becomes a food source for other species (Poovachiranon et al. 1986, Camilleri 1992).

No microalgae were observed in the stomach of Grandidierella sp. Gerdol \& Hughes (1994b) found that microalgae were not detectable in the gut of Corophium volutator, although this amphipod was shown to ingest 4000 cells $h^{-1}$ and to significantly reduce diatom densities. Moreover, Pinckney \& Sandulli

Fig. 9. (a) Oligochaete and (b) total macrobenthos density in the cage, partial cage and blank treatment. Mean values and standard deviations of the upper slice $(0$ to $2 \mathrm{~cm}$ ) over time. Pr significant procedural effect with $p<0.05$, f: factorial design, m: mixed design 
Table 1. Densities (ind. $\mathrm{m}^{-2}$ ) and results of the statistical Kruskal-Wallis and Median tests (with $\mathrm{p}<0.05$ ) for the oligochaete families Tubificidae and Enchytraeidae over 3 periods. B: blank, C: cage and P: partial cage. Bold indicates significance

\begin{tabular}{|c|c|c|c|c|c|c|c|}
\hline & & \multicolumn{2}{|c|}{ Before caging } & \multicolumn{2}{|c|}{22 d after caging } & \multicolumn{2}{|c|}{$112 \mathrm{~d}$ after caging } \\
\hline & & Mean & SD & Mean & SD & Mean & $\mathrm{SD}$ \\
\hline \multirow[t]{5}{*}{ Tubificidae } & Blank & 13040 & 2508 & 379 & 379 & 31928 & 4403 \\
\hline & Cage & 20421 & 828 & 6749 & 4517 & 52202 & 10322 \\
\hline & Partial & 26067 & 10581 & 2390 & 557 & 48962 & 10263 \\
\hline & Kruskal-Wallis & \multicolumn{2}{|c|}{$\mathrm{B}=\mathrm{C} / \mathrm{B}=\mathrm{P} / \mathrm{P}=\mathrm{C}$} & \multicolumn{2}{|c|}{$\mathrm{B}=\mathrm{C} / \mathrm{B}=\mathrm{P} / \mathrm{P}=\mathrm{C}$} & \multicolumn{2}{|c|}{$\mathrm{B}=\mathrm{C} / \mathrm{B}=\mathrm{P} / \mathrm{P}=\mathrm{C}$} \\
\hline & Median & \multicolumn{2}{|c|}{$B \neq C / B=P / P=C$} & \multicolumn{2}{|c|}{$B \neq C / B=P / P=C$} & \multicolumn{2}{|c|}{$\mathrm{B} \neq \mathrm{C} / \mathrm{B} \neq \mathbf{P} / \mathrm{P}=\mathrm{C}$} \\
\hline \multirow[t]{5}{*}{ Enchytraeidae } & Blank & 2733 & 1965 & 800 & 719 & 9455 & 3834 \\
\hline & Cage & 1287 & 1287 & 1548 & 1432 & 6132 & 3459 \\
\hline & Partial & 2714 & 663 & 2271 & 738 & 14128 & 14128 \\
\hline & Kruskal-Wallis & \multicolumn{2}{|c|}{$\mathrm{B}=\mathrm{C} / \mathrm{B}=\mathrm{P} / \mathrm{P}=\mathrm{C}$} & \multicolumn{2}{|c|}{$B=C / B=P / P=C$} & \multicolumn{2}{|c|}{$\mathrm{B}=\mathrm{C} / \mathrm{B}=\mathrm{P} / \mathrm{P}=\mathrm{C}$} \\
\hline & Median & \multicolumn{2}{|c|}{$\mathrm{B}=\mathrm{C} / \mathrm{B}=\mathrm{P} / \mathrm{P}=\mathrm{C}$} & \multicolumn{2}{|c|}{$B=C / B=P / P=C$} & \multicolumn{2}{|c|}{$\mathrm{B}=\mathrm{C} / \mathrm{B}=\mathrm{P} / \mathrm{P}=\mathrm{C}$} \\
\hline
\end{tabular}

(1990) refer to diatoms as an important food source for many amphipods.

The exclusion effect on this genus can possibly be related to 3 types of interactions:

(1) Predation on amphipods: Stomach analysis of the permanent epibenthos revealed little predatory evidence (Table 2). Possible predation by the visiting fauna might have been minor compared with the competitive influence of the permanent epifauna.

(2) Competition for leaf material: The amphipod gut content analysis and the findings of Poovachiranon et al. (1986) and Camilleri (1992) suggest that resource competition for leaves is an acceptable explanation for the exclusion effect which was found. The exclusion of Sesarma meinerti, which mainly feeds on mangrove leaves (Table 2), could have been the direct inducement to the amphipods' increase in the cage. On the other hand, Camilleri (1989) argued that this resource competition for leaves and leaf particles may be facilitated by the availability of different particle sizes. Sesarma meinerti takes whole leaves and large particles while small shredders like amphipods are restricted to rather small particles. Moreover, the role of direct bacterial decomposition of the leaves could also have gained in importance (Robertson \& Danicl 1989).

(3) Competition for microalgae and deposited food: The excluded epibenthos was dominated by deposit and a. Polychaete density (ind $/ \mathrm{m}^{2}$ )

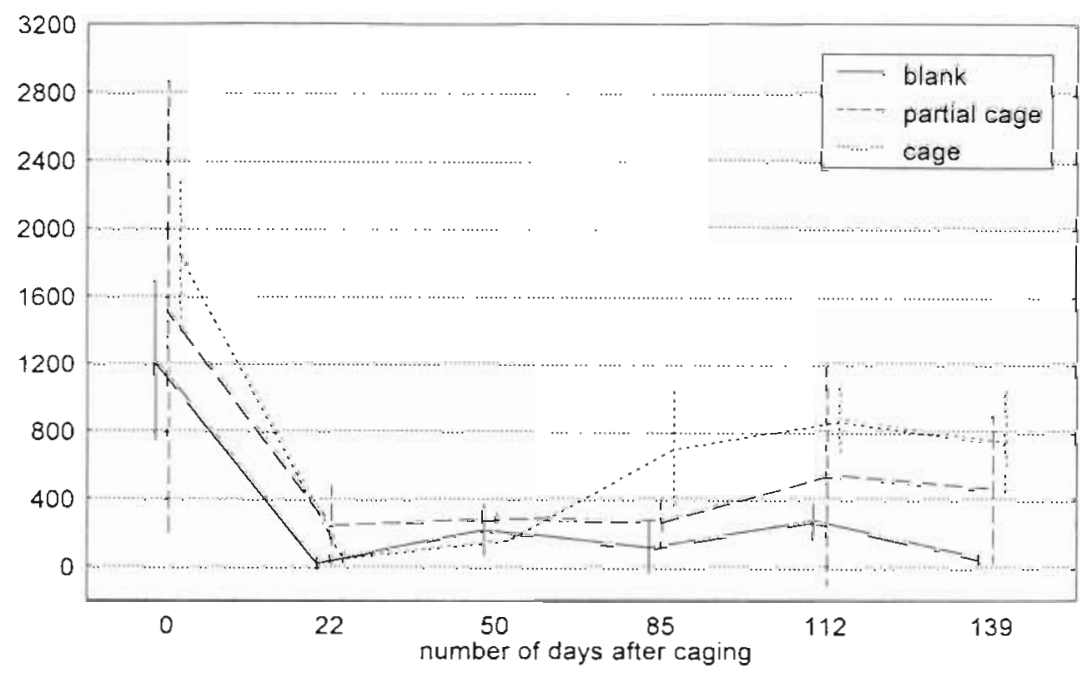

b. Nematode density (ind $/ \mathrm{m}^{2}$ )

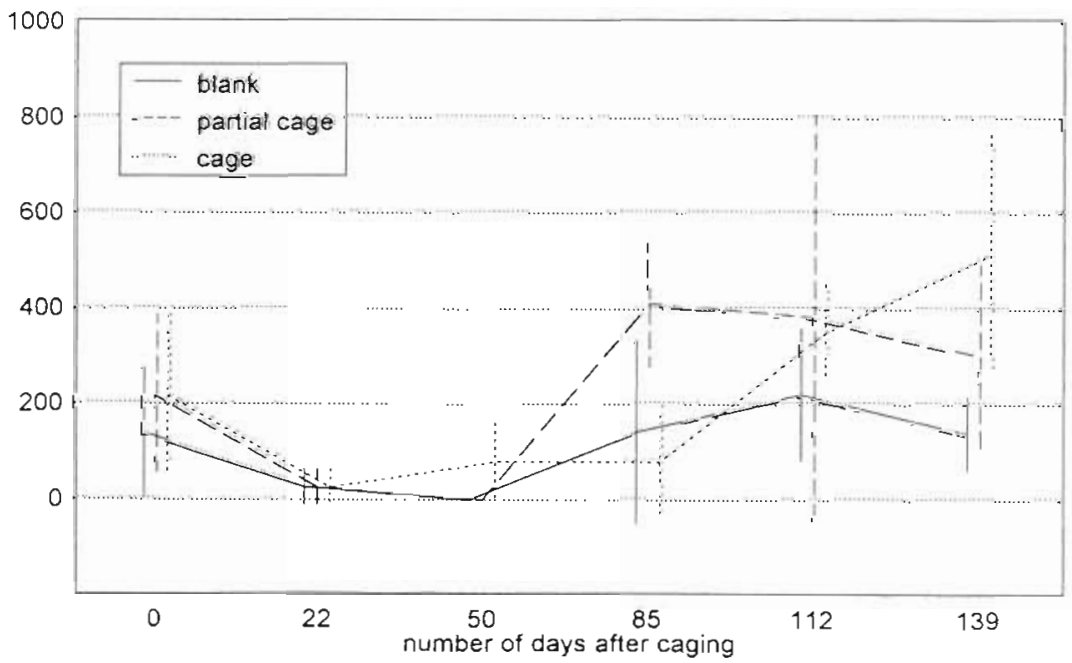

Fig. 10. (a) Polychaete and (b) nematode densities in the cage, partial cage and blank treatment. Mean values and standard deviations of the upper slice $(0$ to $2 \mathrm{~cm}$ ) over time 
Table 2. Description of permanent and visiting epibenthos excluded from the cages in the Avicennia marina zone studied (in terms of average densities, feeding behaviour and habitat)

\begin{tabular}{|c|c|c|c|c|}
\hline Epibenthic species & Source & Feeding behaviour & Habitat & $\begin{array}{l}\text { Average density } \\
\left.\text { t. } \mathrm{m}^{-2}\right) \text { (this study) }\end{array}$ \\
\hline Cerithidea decollata & $\begin{array}{l}\text { Brown (1971) } \\
\text { McIntosh (1984) } \\
\text { Dye \& Lasiak (1987) }\end{array}$ & $\begin{array}{l}\text { Non-selective deposit } \\
\text { feeding (detritus) }\end{array}$ & $\begin{array}{l}\text { Frequently } \\
\text { on trees }\end{array}$ & 57 \\
\hline Terebralia palustris & Dye \& Lasiak (1987) & $\begin{array}{l}\text { Non-selective deposit feeding } \\
\text { (inorganic parts, microalgae, } \\
\text { bacteria, protozoans) }\end{array}$ & $\begin{array}{l}\text { Sediment } \\
\text { dwelling }\end{array}$ & 36 \\
\hline Sesarma meinerti & $\begin{array}{l}\text { Cott (1929) } \\
\text { Emmerson \& } \\
\text { McGwynne (1992) } \\
\text { Steinke et al. (1993) }\end{array}$ & $\begin{array}{l}\text { Vegetarian } \\
\text { Omnivorous with preference } \\
\text { for leaves ( } 75 \% \text { of diet) }\end{array}$ & $\begin{array}{l}\text { Sediment } \\
\text { dwelling }\end{array}$ & $\begin{array}{l}0.25 \\
\left(1 \text { burrow } \mathrm{m}^{-2}\right)\end{array}$ \\
\hline Metopograpsus thukuhar & $\begin{array}{l}\text { F. Dahdouh-Guebas et } \\
\text { al. (pers. conun.) } \\
\text { McIntosh (1988) }\end{array}$ & $\begin{array}{l}\text { Omnivorous with preference } \\
\text { for macroalgae and anımal } \\
\text { items (sometimes fresh leaves, } \\
\text { seedlings, leaf litter and detritus) }\end{array}$ & $\begin{array}{l}\text { Forest dweller } \\
\text { (trunk, roots, floor) }\end{array}$ & 1 \\
\hline $\begin{array}{l}\text { Visiting fauna } \\
\text { (unknown) }\end{array}$ & $?$ & Herbivorous or carnivorous? & $\begin{array}{l}\text { High tidal (only } \\
\text { during spring tides) }\end{array}$ & $?$ \\
\hline
\end{tabular}

microalgae feeders (Table 2). In spite of the absence of microalgae in their stomachs, the exclusion effect on amphipods was detected 1 mo after the detection of a clear exclusion effect on the concentration of chlorophyli a. As soon as amphipod cage densities

Table 3. Qualitative observations (-: absent, +: present, \pm : intermediate) after 1 and 5 mo of caging with an evaluation of the procedure. B: blank, C: cage, P: partial cage

\begin{tabular}{|lcccccccl|}
\hline \multirow{4}{*}{ Artefact } & \multicolumn{4}{c}{ After 1} & mo caging & & \multicolumn{4}{c|}{ After 5 mo caging } & Evaluation \\
& $\mathrm{B}$ & $\mathrm{C}$ & $\mathrm{P}$ & $\mathrm{B}$ & $\mathrm{C}$ & $\mathrm{P}$ & \\
\hline Fouling & - & - & - & - & - & - & OK \\
Shading & - & + & \pm & & - & + & \pm & \pm procedural \\
Sedimentation & - & - & - & - & - & - & OK \\
Moisture & - & + & + & & - & + & + & Procedural \\
Litter fall & + & - & - & + & - & - & OK \\
Epibenthos & + & - & + & & + & - & + & OK \\
\hline
\end{tabular}

Table 4. Effect size (f) per taxon with the 'between treatment' variance (MS $\mathrm{S}_{\text {effect), }}$ the 'error' variance ( $\mathrm{MS}_{\text {error }}$ ) and the estimated magnitude of treatments $\left(\eta^{2}\right)$ (calculated via tables and formulas provided by Cohen 1977)

\begin{tabular}{|llccrcc|}
\hline Taxon & Design & MS $_{\text {effect }}$ & MS $_{\text {error }}$ & $\eta^{2}$ & $f$ & Power \\
\hline \multirow{2}{*}{ Polychaeta } & Factorial & 3.48393 & 2.506394 & 0.07 & 0.274 & $11 \%$ \\
& Mixed & 3.48393 & 2.845246 & 0.04 & 0.05 & $5 \%$ \\
Nematoda & Factorial & 1.98072 & 1.930757 & 0.005 & 0.05 & $5 \%$ \\
& Mixed & 1.98072 & 2.601394 & 0.04 & 0.05 & $5 \%$ \\
\hline
\end{tabular}

increased, the microalgal peak started to return to its former level. In addition the indirect exclusion effect on muddy detritus paralleled the exclusion effect on amphipods and the amphipods' stomachs contained a clear detrital fraction.

This kind of competition is believed to be the determining factor.

Insect larvae density. According to O'Meara (1976), marine insect larvae are basically omnivores (mainly browsers and filter feeders). The resource competition hypothesis (as discussed for amphipods) would be supported if most insect larvae found were browsers abrading solid material and manipulating and breaking down leaf and detritus particles. However, most of the larvae in this study belonged to the Dolichopodidae family (B. Goddeeris pers. comm.) whose members are predaceous and are frequently found in damp soil, sand and rotting wood in the intertidal zone (Smith 1989). Examination of gut contents of the Dolichopodidae found in this study revealed a high number of oligochaete setae.

O'Meara (1976) mentioned that fish and other insects were the main 
predators on insect larvae. Still, no larvivorous fishes have been described for the studied area (J. Mees pers. comm.).

Oligochaete and total densities. Both densities were closely linked since oligochaetes made up the largest part of the total infaunal macrobenthos.

Procedural effects on oligochaetes have been documented before and are thought to be a result of sediment modification caused by the cage construction (Hulberg \& Oliver 1980, Hall et al. 1990a). The procedural effect in our study could possibly be linked with changes in environmental factors due to cage construction

(1) Salinity lt has been stated that this factor is crucial in determining oligochaete distribution (Giere 1980, Giere \& Pfannkuche 1982). This holds especially for salinity of tropical, intertidal areas where $40 \mathrm{psu}$ is the upper tolerance limit for oligochaetes (Giere \& Pfannkuche 1982).

(2) $\mathrm{pH}$ : Tolerance experiments (Giere 1977 in Giere \& Pfannkuche 1982) showed that extreme alkalinities (exceeding 9) in combination with high salinities and temperatures could cause a deterioration of viability in interstitial tubificids. No such conditions were found in this experiment.

(3) Light intensity: The shadow caused by the construction cover could possibly have induced an upward vertical migration of littoral, negatively phototactic oligochaetes (Giere \& Pfannkuche 1982).

(4) Mud: The decrease in grain size could have influenced habitat selection. However, this is more relevant in mesopsammic forms for which interstitial space is a crucial condition for life (Giere \& Pfannkuche 1982).

Nevertheless, most studies concentrating on oligochaete densities in temperate areas found successful exclusion effects. It is usually concluded that these effects are a result of predation exclusion (Reise 1977. 1978, Kneib \& Stiven 1982, Connell 1983, Gee et al. 1985). The only experimental study dealing with oligochaetes of mangrove sediments was that of Schrijvers et al. (1995), which indicated that meiobenthic oligochaetes are influenced by competition with the deposit-feeding epibenthos rather than by predation. The slight increase of the oligochaete density in the cage after $112 \mathrm{~d}$ (which was not statistically significant) could also be a response to the indirect exclusion effect on the muddy detritus. The most important dietary item for interstitial tubificids and enchytraeids is believed to be organic matter (detritus) enriched with bacteria (Giere \& Pfannkuche 1982).

Polychaete and nematode densities. As found for nineioberthic polychuctos in a Ceriops tagal mangrnve. sediment (Schrijvers et al. 1995), macro-polychaetes did not show an exclusion effect. However, in other experimental studies in seagrass beds (Reise 1978,
1979) and in mudflats (Reise 1978) polychaetes reacted positively to epibenthic exclusion.

Some studies have shown the number of meiobenthic nematodes to double in the cage sediment in contrast with the control cages after 2 mo of epibenthic exclusion (Reise 1979, Schrijvers et al. 1995). The macronematodes in our study all belonged to the family of Oncholaimidae. These are believed to be scavengers with a very broad diet that stimulate bacterial and fungal metabolism by decomposing organic matter (Lopez et al. 1979, Jensen 1987). This alternative feeding behaviour could possibly have kept this group from being influenced by resource competition.

The absence of significant effects for polychaetes and nematodes possibly results from the efficiency of the experimental design to detect effects. Parameters significance levels (0.05), effect sizes ( $f$ ), and the number of treatment groups (18) resulted in power levels of $8 \%$ for polychaetes and $5 \%$ for nematodes (average power for factorial and mixed design) (Hall et al. 1990b). The effect size (f) per taxon (Table 4) was calculated via the ANOVA variances, the number of degrees of freedom (10), of groups (18), and of replicates within a group (3). The power levels point to the chance of avoiding a type II error $(1-\beta)$ and were calculated via the power table provided by Cohen (1977). The low levels could possibly result in an undetectable influence.

\section{CONCLUSION}

Oligochaete, polychaete and macro-nematode densities were not positively affected after epibenthic exclusion. The positive exclusion effect on the amphipod community seems to point to a resource competition with the dominant epibenthos for microalgae, muddy detritus and, possibly, for leaves. No driving force for the conspicuous positive exclusion effect on insect larvae could be found. However, in this case too, predatory exclusion is believed to be unimportant.

Therefore, the predation hypothesis is thought to be minor as an interaction between the epibenthos and macrobenthic infauna under the Avicennia marina stand studied. A resource competitive effect caused by the permanent epibenthos is found to be more conspicuous. The question whether epibenthic predation on endobenthos from this high intertidal mangrove forest floor is present or absent remains to be answered.

Acknowledgements. Financial support was given by the FKFO-programme 32.0043 .88 and 32.0009 .92 of the Belgian National Fund for Sclentı1ı Research and the Kenya-Deiyiun Project in Marine Sciences in cooperation with the EC project 'Dynamics and Assessment of the Mangrove Ecosystem in Kenya' The work was performed at the Kenya Marine and 
Fisheries Research Institute in Mombasa (Dr E. Okemwa) and at the Section of Marine Biology in Gent. Julius Okondo, Ann Vanreusel, Jan Mees, Steven Degraer and Sandra Vanhove offered valuable comments on earlier versions of the manuscript. The help of the technical staff of the Institute of Zoology and the K.M.F.R.I. was indispensable to the sampling and sample processing (special thanks to $M$. Beghyn, $M$. Bruyneel, G. De Smet, W. Gyselinck, N. Lefèvre, A. Ototo, D Schram, J. Van de Velde, D. Van Gansbeke, A. Van Kenhove A. Vierstraete, and the people of Gazi). The first author acknowledges a grant from the Belgian National Fund for Scientific Research (N.F.W.O.)

\section{LITERATURE CITED}

Admiraal W (1977) Influence of light and temperature on the growth rate of estuarine benthic diatoms in culture. Mar Biol 39:1-9

Alongi DM (1989) The role of soft-bottom benthic communities in tropical mangrove and coral reef ecosystems. Rev Aquat Sci 1:243-280

Bell SS (1980) Melofauna-macrofauna interactions in a high salt marsh habitat. Ecol Monogr 50:487-505

Brown DS (1971) Ecology of Gastropoda in a South African mangrove swamp. Proc Malac Soc Lond 39:263-278

Camilleri J (1989) Leaf choice by crustaceans in a mangrove forest in Queensland. Mar Biol 102:453-459

Camilleri JC (1992) Leaf-litter processing by invertebrates in a mangrove forest in Queensland. Mar Biol 1 14:139-145

Cohen J (1977) Statistical power analysis for the behavioural sciences. Academic Press, New York

Connell JH (1983) On the prevalence and relative importance of interspecific competition: evidence from field experiments. Am Nat 122(5):661-695

Cott HB (1929) Observations on the natural history of the land-crab Sesarma meinerti, from Beira, with special reference to the theory of warning colours. Proc Zool Soc Lond 46:679-692

Day JH (1967) A monograph on the Polychaeta of Southern Africa, Part I, Errantia. Trustees of the British Museum (Natural History), London

Dittman S (1993) Impact of foraging soldiercrabs (Decapoda: Mictyridae) on meiofauna in a tropical tidal flat. Rev Biol Trop 41(3):627-637

Dye AH, Lasiak TA (1986) Microbenthos, meiobenthos and fiddler crabs: trophic interactions in a tropical mangrove sediment. Mar Ecol Prog Ser 32:259-264

Dye AH, Lasiak TA (1987) Assimilation efficiencies of fiddler crabs and deposit-feeding gastropods from tropical mangrove sediments. Comp Biochem Physiol 87 A(2):341-344

Emmerson WD, McGwynne LE (1992) Feeding and assimilation of mangrove leaves by the crab Sesarma meinerti de Man in relation to leaf litter production in Mgazana a warm-temperate southern African mangrove swamp J Exp Mar Biol Ecol 157(1):41-53

Federle TW, Livingston RJ, Meeter DA, White DC (1983) Mod. ifications of estuarine sedimentary microbiota by exclusion of epibenthic predators. J Exp Mar Biol Ecol 73:81-94

Gee JM, Warwick RM, Davey JT, George CL (1985) Field experiments on the role of epibenthic predators in determining prey densities in an estuarine mudflat. Estuar Coast Shelf Sci 21:429-448

Gerdol V. Hughes RG (1994a) Effect of Corophium volutator on the abundance of benthic diatoms, bacteria and sediment stability in two estuaries in southeastern England Mar Ecol Prog Ser 114:109-115
Gerdol V, Hughes RG (1994b) Feeding behaviour and diet of Corophum volutator in an estuary in southeastern England. Mar Ecol Prog Ser 114:103-108

Giere $O(1980)$ Tolerance and preference reactions of marine Oligochaeta in relation to their distribution. In: Brinkhurst RO, Cook DG (eds) Aquatic oligochaete biology. Plenum Publishing Corporation, New York, p 385-409

Giere O. Pfannkuche O (1982) Biology and ecology of marine Oligochaeta, a review. Oceanogr Mar Biol A Rev 20: $173-308$

Hall SJ, Raffaelli D, Basford DJ, Roberston MR (1990a) The importance of flatfish predation and disturbance on marine benthos: an experiment with dab Limanda limanda (L.). J Exp Mar Biol Ecol 136:65-76

Hall SJ, Raffaelli D, Robertson MR (1990b) The role of the predatory crab, Liocarcinus depurator, in a marine food web. J Anim Ecol 59:421-438

Heip C, Vincx M, Vrancken G (1985) The ecology of marine nematodes. Oceanogr Mar Biol A Rev 23:399-489

Hoffman JA, Katz J, Bertness MD (1984) Fiddler crab depositfeeding and meiofaunal abundance in. salt marsh habitats. J Exp Mar Biol Ecol 82:161-174

Holland AF, Mountford NK, Hiegel $\mathrm{MH}$, Kaumeyer $\mathrm{KR}$, Mihursky JA (1980) Influence of predation on infaunal abundance in Upper Chesapeake Bay, USA. Mar Biol 57: $221-235$

Holme NA, McIntyre AD (1984) Methods for the study of marine benthos. Blackwell Scientific Publications, London

Hulberg WL, Oliver JS (1980) Caging manipulations in marine soft-bottom communities: importance of animal interactions or sedimentary habitat modifications. Can J Fish Aquat Sci 37:1130-1139

Hurlbert SH (1984) Pseudoreplication and the design of ecological field experiments. Ecol Monogr 54:187-211

Hutchings P, Saenger P (1987) Ecology of mangroves. University of Queensland Press, St Lucia, Australia

Jensen P (1987) Feeding ecology of free-living aquatic nematodes. Mar Ecol Prog Ser 35:187-196

Knelb RT, Stıven AE (1982) Benthic invertebrate responses to size and density manipulations of the common mummichog, Fundulus heteroclitus, in an intertidal salt marsh. Ecology 63(3): 1518-1532

Lopez G, Riemann F, Schrage M (1979) Feeding biology of the brackish-water oncholaimid nematode Adoncholaimus thalassophygas. Mar Biol 54:311-318

Mantoura RFC, Llewellyn CA (1983) The rapid determination of algal chlorophyll and carotenoid pigments and their breakdown products in natural waters by reverse-phase high performance liquid chromatography. Analyt Chim Acta 151:297-314

Marinelli RL, Coull BC (1987) Structural complexity and juvenile fish predation on meiobenthos: an experimental approach. J Exp Mar Biol Ecol 108:67-81

McIntosh DJ (1984) Ecology and productivity of Malaysian mangrove crab populations (Decapoda: Brachyura). Proc Asian Symp Mangrove Environ, Res Manag 1:354-377

McIntosh DJ (1988) The ecology and physiology of decapods of mangrove swamps. Symp Zool Soc Lond 59: $315-341$

Menge BA. Lubchenco J, Ashkenas RL (1986) Experimental separation of consumers on sessil prey in the low zone of a rocky shore in the Bay of Panama: direct and indirect consequences of food web complexity. J Exp Mar Biol Ecol 100:225-269

O'Meara, GF (1976) Saltmarsh mosquitoes (Diptera: Culicidae). In: Cheng L (ed) Marine insects. North-Holland Publishing Company, Amsterdam, p 303-333 
Orth RJ (1977) The importance of sediment stability in seagrass communities. In: Coull BC (ed) Ecology of manne benthos. University of South Carolina Press, Columbia, p 281-300

Pinckney J, Sandulli R (1990) Spatial autocorrelation analysis of meiofaunal and microalgal populations on an intertidal sandflat: scale linkage between consumers and resources. Estuar Coast Shelf Sci 30:341-353

Platt HM, Warwick RM (1988) Freeliving marine nematodes, Part II, British chromadorids. In: Kermack DM, Barnes RSK (eds) Synopses of the British fauna, no. 38. EJ Brill \& W Backhuys, Leiden

Poovachiranon S, Boto K, Duke N (1986) Food preference studies and ingestion rate measurements of the mangrove amphipod Parbyale hawaiensis (Dana). J Exp Mar Biol Ecol 98:129-140

Reise K (1977) Predator exclusion experiments in an intertidal mud flat. Helgoländer Wiss Meeresunters 30:263-271

Reise K (1978) Experiments on epibenthic predation in the Wadden Sea. Helgoländer Wiss Meeresunters 31:55-101

Reise K (1979) Moderate predation on meiofauna of the macrobenthos of the Wadden Sea. Helgoländer Wiss Meeresunters 32:453-465

Reise K (1985) Tidal flat ecology - an experimental approach to species interactions. Springer-Verlag, Heidelberg

Robertson AI, Daniel PA (1989) The influence of crabs on litter processing in high intertidal mangrove forests in tropical Australia. Oecologia 78:191-198

Schrijvers J, Okondo J, Steyaert M, Vincx M (1995) Influence of epibenthos on meiobenthos of the Ceriops tagal mangrove sediment at Gazi Bay, Kenya. Mar Ecol Prog Ser 128:247-259

This article was submitted to the editor
Smith KGV (1989) An introduction to the immature stages of British flies: Diptera larvae, with notes on eggs, puparia and pupae. In: Dolling WR, Askew RR (eds) Handbooks for the identification of British insects, Vol 10, Part 14 . Royal Entomological Society of London, London

Steinke TD, Rajh A, Holland AJ (1993) The feeding behaviour of the red mangrove crab Sesarma meinerti de Man, 1887 (Crustacea: Dncapoda: Grapsidae) and its effect on the degradation of mangrove leaf litter. S Afr J Mar Sci 13: 151-160

Tietjen JH, Alongi DM (1990) Population growth and effects of nematodes on nutrient regeneration and bacteria associated with mangrove detritus from northeastern Queensland (Australia). Mar Ecol Prog Ser 68:169-179

Virnstein RW (1977) The importance of predation by crabs and fishes on benthic infauna in Chesapeake Bay. Ecology 58:1199- 1217

Virnstein RW (1978) Predator caging experiments in soft sediments: caution advised. In: Wiley ML (ed) Estuarine interactions. Academic Press, New York, p 261-273

Virnstein RW (1979) Predation on estuarine infauna: response patterns of component species. Estuaries 2(2):69-86

Woodin SA (1981) Disturbance and community structure in a shallow water sand flat. Ecology 62(4):1052-1066

Young DK, Buzas MA, Young MW (1976) Species densities of macrobenthos associated with seagrasses: a field experimental study of predation. J Mar Res 34:577-592

Young DK, Young MW (1977) Community structure of the macrobenthos associated with seagrass of the Indian River estuary, Florida. In: Coull BC (ed) Ecology of marine benthos. University of South Carolina Press, Columbia, p 359-382

Manuscript first received: June 12, 1995

Revised version accepted: January 8, 1996 